\title{
ERROR ANALYSIS IN SOLVING STRAIGHT MOTIONS' PROBLEMS OF SENIOR HIGH SCHOOL STUDENTS IN PEKANBARU
}

\author{
Vetty Vellancia ${ }^{* 1)}$, Zulirfan $^{2)}$, Hendar Sudrajad ${ }^{3)}$ \\ ${ }^{1,2,3)}$ Physics Education, University of Riau \\ e-mail: vettyvella@gmail.com \\ zulirfan@lecturer.unri.ac.id
}

\begin{abstract}
Errors are deviations from things that have been known to be true, errors by students in solving problems can be used by the teacher as a tool in knowing the extent of student ability, so that it can be known the difficulties experienced by students in the learning process. The purpose of this research is to describe the types of errors made by students in solving physics problems on straight motion material at SMAN 5 Pekanbaru. Population in this research were 360 students of class X SMAN 5 Pekanbaru. Samples were taken randomly and a total of 72 students were obtained. This research instrument was in the form of essay questions which were arranged based on the types of errors commonly made by students. Data was collected by giving essay test questions to the research sample. Data analysis in this research uses descriptive analysis with percentage techniques, which provide an overview of the level of errors made by students. Using the six questions that were tested, the most dominant type of error was obtained by students, namely the types of concept errors and data calculation errors, while the types of errors that were least experienced by students were the types of mathematical errors. For this reason, in learning physics on the topic of GLBB in class $X$ SMA N 5 Pekanbaru, it is necessary to emphasize understanding of concepts and calculation of data that is more optimal so that students get better learning outcomes.
\end{abstract}

Keywords: error analysis, straight motion, physics problem solving. 


\title{
ANALISIS KESALAHAN DALAM MENYELESAIKAN MASALAH GERAK LURUS SISWA SMA DI PEKANBARU
}

\author{
Vetty Vellancia ${ }^{* 1)}$, Zulirfan ${ }^{2)}$, Hendar Sudrajad ${ }^{3)}$ \\ ${ }^{1,2,3)}$ Pendidikan Fisika, Universitas Riau
}

\begin{abstract}
Abstrak
Kesalahan merupakan penyimpangan dari hal yang sudah diketahui kebenarannya, kesalahan-kesalahan yang dilakukan oleh siswa dalam menyelesaikan soal dapat digunakan guru sebagai alat bantu dalam mengetahui sejauh mana kemampuan siswa, sehingga dapat diketahui kesulitan-kesulitan yang dialami siswa dalam proses pembelajaran. Tujuan penelitian ini adalah mendeskripsikan jenis-jenis kesalahan yang dilakukan oleh siswa dalam menyelesaikan soal-soal fisika pada materi gerak lurus di SMAN 5 Pekanbaru. Populasi dalam penelitian ini adalah 360 siswa kelas X SMAN 5 Pekanbaru. Sampel diambil secara random dan diperoleh sampel yang berjumlah 72 siswa. Instrumen penelitian ini berupa soal esai yang disusun berdasarkan jenis kesalahan yang umum dilakukan oleh siswa. Data dikumpulkan dengan cara memberikan soal tes esai kepada sampel penelitian. Analisis data pada penelitian ini menggunakan analisis deskriptif dengan teknik persentase, yang memberikan gambaran tentang tingkat kesalahan yang dilakukan oleh siswa. Hasil penelitian memberikan informasi bahwa terdapat enam (6) jenis kesalahan yang sering dilakukan oleh siswa. Menggunakan 6 soal yang diujikan, diperoleh jenis kesalahan yang paling dominan terjadi oleh siswa yaitu jenis kesalahan konsep dan kesalahan menghitung data, sedangkan jenis kesalahan yang paling sedikit dialami siswa yaitu jenis kesalahan matematis. Untuk itu, dalam pembelajaran fisika pada materi GLBB di kelas X SMA N 5 Pekanbaru, perlu penekanan pada pemahaman konsep dan penghitungan data yang lebih optimal agar siswa memperoleh hasil belajar yang lebih baik.
\end{abstract}

Kata Kunci: analisis kesalahan, gerak lurus, penyelesaian masalah fisika.

\section{Pendahuluan}

Fisika merupakan ilmu universal yang mendasari perkembangan teknologi modern, mempunyai peran penting dalam berbagai disiplin ilmu, dan mengembangkan daya pikir manusia. Ilmu Pengetahuan Alam (IPA) merupakan ilmu yang mempelajari tentang fenomena alam dan segala sesuatu yang ada di alam. Fisika merupakan mata pelajaran dalam rumpun sains yang dapat mengembangkan kemampuan berpikir analitis dalam menyelesai kan masalah yang berkaitan dengan peristiwa alam sekitar, baik secara kualitas maupun kuantitas menggunakan bantuan matematika (Depdiknas, 2003).

Menurut Riskowati (2013) Fisika memiliki kaitan erat dengan matematika. Hal ini karena matematika mampu menyediakan kerangka logika dimana hukum-hukum fisika dapat diformulasikan secara tepat. Definisi, teori dan model fisika selalu dinyatakan mengunakan hubungan matematis. Fisika tidak berjalan tanpa matematika, karena konsep tentang alam ini tidak akan bisa diutarakan dan dimanfaatkan dengan baik tanpa bantuan konsep matematika (Nathanael Mariono, 2011). Erat kaitannya antara penguasaan konsep fisika untuk mengerjakan soal-soal fisika pada materi gerak.

Pandangan bahwa fisika sekedar rumus sangat jauh dari inti pelajaran fisika. Sebab, kemampuan perhitungan matematis siswa menggunakan rumus penting untuk memantapkan penguasaan hukum alam yang telah mereka kuasai. Tapi, perlu ditegaskan bahwa kemampuan perhitungan matematis akan diperoleh jika siswa bisa menguasai konsep dasar yang dipelajari yang tidak diperoleh dari hafalan semata (Wijayanto, 2008).

Pembelajaran fisika di sekolah dimaksudkan agar siswa mampu menguasai konsep-konsep fisika, serta mengaplikasikannya dalam kehidupan sehari-hari. Menguasai konsep bukan sekedar mengetahui saja, tetapi juga memahami konsep fisika tersebut. Penguasaan konsep-konsep fisika siswa tersebut tampak ketika siswa mampu menyelesaikan soal-soal fisika. Siswa dalam pembelajaran fisika harus dapat memahami 
konsep-konsep fisika dan mampu menerapkan nya dalam aktivitas pemecahan masalah fisika agar mencapai keberhasilan belajar. Keberhasilan belajar dapat dilihat dari pencapaian hasil belajar. Hasil belajar menurut Pahini Nani (2013) adalah hasil dari suatu interaksi tindakan belajar mengajar dan ditinjukkan hasilnya dengan nilai tes yang diberikan.

Hasil penelitian Sufi Ani (2011) didapat hasil jenis kesalahan yang dilakukan siswa dalam menyelesaikan soal-soal pada materi pokok Momentum dan Implus dimana kesalahan yang dialami siswa meliputi kesalahan strategi, kesalahan terjemahan, kesalahan konsep, kesalahan hitung, dan kesalahan tanda. Hasil penelitian Muhammad Hasbi (2012) mengetahui adanya pengaruh kemampuan Trigonometri terhadap kemampuan fisika dari mahasiswa progam studi pendidikan Fisika FKIP UNTAN. Hasil penelitian Kereh (2014) mengindikasikan bahwa materi matematika dasar yang diuji sangat relevan dengan materi perkuliahan pendahuluan fisika inti yang dilakukan.

Terlihat dari beberapa hasil penelitian tersebut, dapat dikatakan bahwa kesalahan siswa sangat berpengaruh dalam penyelesaian soal fisika. Penyelesaian soal fisika merupakan suatu bentuk dari hasil evaluasi belajar siswa dalam pelajaran fisika. Dimana dalam evaluasi terdapat kegiatan mengukur dan menilai kemampuan siswa dalam memahami pelajaran (Haryadi, 2015).

Tetapi banyaknya kesalahan tersebut sering kali diabaikan, tanpa adanya tindak lanjut untuk mengetahui kesalahan-kesalahan yang terjadi pada siswa saat mengerjakan soalsoal fisika, karena kurangnya tindak lanjut untuk mengetahui jenis kesalahan-kesalahan yang dilakukan siswa tersebut, mengakitbatkan kesalahan-kesalahan dalam mengerjakan soal fisika akan terus terjadi (Andika Rahmat, 2016).

Guru berperan penting dalam menilai keberhasilan siswa, tidak cukup hanya sekedar mengetahui berhasil atau tidaknya siswa dalam menyelesaikan soal atau tes, dan dari nilai yang diperoleh siswa tetapi para guru juga harus senantiasa melakukan pemeriksaan dari hasil kerja siswa atau analisis terhadap jawaban. Analisis terhadap jawaban dilakukan untuk mengetahui bagian mana dari materi yang belum dikuasai, menemukan kelemahan atau kesulitan siswa, penyebab kesulitan siswa dan sejauhmana konsep-konsep fisika tersebut dapat dipahami siswa.

Guru memiliki tanggup jawab melakukan diagnosis dengan cermat terhadap kesulitan dan kebutuhan peserta didik. Diagnosis ini diperlukan agar guru dapat menindaklanjuti kesalahan yang dilakukan peserta didik dalam mengerjakan soal, sehingga diharapkan diperoleh hasil belajar yang lebih baik (Agustini Baya Sari, 2015). Secara etimologis diagnostik berasal dari bahasa inggris "diagnostic". Mendiagnosis berarti melakukan observasi terhadap penyakit tertentu untuk bidang kesehatan, sebagai dasar menentukan jenis peyakit. Sedangkan, tes diagnostik di bidang pembelajaran dirancang sebagai alat untuk menemukan kesulitan belajar ataupun miskonsepsi yang dihadapi peserta didik (Tri Wahyuningsih, et al., 2013). Kesalahan yang dilakukan siswa dalam menyelesaiakan soal dapat digunakan guru sebagai alat bantu melihat sejauh mana pemahaman siswa dalam proses belajar yang telah berlangsung sehingga akan diketahui kesulitan-kesulitan siswa (Dewi \& Kusrini, 2015).

Menurut Hastuti et. al. (2012), menyatakan beberapa jenis kesalahan siswa dalam menyelesaikan soal yaitu:

a. Kesalahan konsep yaitu kesalahan terkait prinsip atau rumus untuk menjawab soal.

b. Kesalahan menggunakan data yaitu ketika tidak menggunakan data yang seharusnya dipakai, kesalahan memasukkan data ke simbol fisika, dan menambah data yang tidak diperlukan dalam menjawab suatu soal.

c. Kesalahan hitung, merupakan kesalahan dalam menghitung, seperti menjumlahkan, mengurangi, mengalikan, dan membagi.

d. Kesalahan strategi adalah kesalahan dalam mengambil langkah penyelesaian soal sehingga menimbulkan kesulitan bagi siswa sendiri dan tidak bermanfaat dalam penyelesaian soal.

e. Soal tidak direspon, dimana siswa tidak memberikan jawaban dari soal yang diberikan.

f. Kesalahan matematis yaitu kesalahan dalam membolak-balikan rumus yang ada untuk menyesuaikan dengan pertanyaan yang ditanya dalam soal. 
Bedasarkan hasil kajian (Andika Rahmat (2016), mendapatkan banyaknya kesalahan yang dilakukan siswa saat menjawab soal materi Hukum Kirchoff, maka perlu diadakan penelitian yang mengungkap jenis-jenis kesalahan dan penyebab kesalahan yang dilakukan oleh siswa dalam menyelesaikan soal-soal fisika pada materi gerak lurus. Dengan ini, diharap diperoleh informasi yang diiginkan dan dapat dijadikan acuan untuk melakukan tindakan perbaikan dan antisipasi agar kesalahan-kesalahan tersebut tidak terulang kembali. Selain itu dapat dijadikan sebagai acuan untuk memperbaiki kesalahan (miskonsepsi) yang ada, sehingga dapat meningkatkan hasil belajar fisika siswa kelas X SMA Negeri 5 Pekanbaru khususnya pada materi gerak lurus. Pengungkapan jenis-jenis kesalahan dan penyebab kesalahan tersebut dilakukan dengan menganalisis kesalahan siswa dalam menyelesaikan soal-soal fisika pada materi gerak lurus.

\section{Bahan dan Metode}

Penelitian dilakukan di SMA Negeri 5 Pekanbaru tahun pelajaran 2017/2018 yang menerapkan Kurikulum 2013. Populasi penelitian adalah siswa kelas $\mathrm{X}$ SMAN 5 Pekanbaru yang terdiri dari 10 kelas dengan jumlah siswa 360 orang. Semua kelas termasuk dalam kelompok MIPA yang memiliki jumlah siswa dengan rata-rata yang sama, dan diambil kelas X MIPA ${ }_{1}$ dan X $\mathrm{MIPA}_{2}$ dengan jumlah 72 orang siswa sebagai sampel melalui teknik random.

Jenis penelitian yang digunakan adalah penelitian survei. Penelitian dilakukan dengan mengambil informasi atau data secara langsung terhadap subjek penelitian (Nanang Martono, 2010). Instrumen yang digunakan adalah soal tes esai yang sudah divalidari oleh tim dosen pakar dengan jumlah tes sebanyak 6 soal. Tes tersebut disusun berdasarkan indikator kesalahan yang umum dilakukan siswa.

Teknik analisis data menggunakan analisis deskriptif. Analisis deskriptif digunakan untuk memberikan gambaran tentang jenis-jenis kesalahan yang umum dilakukan oleh siswa. Hasil perolehan data dipersentasekan kesalahan disetiap butir soal untuk mendapatkan total kesalahan yang terjadi pada setiap jenis kesalahan yang dilakukan oleh siswa.

\section{Hasil dan Pembahasan}

Data hasil penelitian survei yang telah dilakukan di SMA Negeri 5 Pekanbaru dengan jumlah sampel 72 orang siswa, diperoleh hasil menggunakan tes diagnostik materi kinematika gerak lurus. Perhitungan dan analisis rata-rata persentase kesalahan tiap butir soal dan setiap jenis kesalahan dilakukan sesuai dengan data yang telah diperoleh.

Berdasarkan analisis deskriptif data hasil tes diagnostik, diperoleh persentasse kesalahan siswa pada setiap jenis kesalahan di masing-masing butir soal yang dapat dilihat pada Tabel 1. Selanjutnya Tabel 1 menjelaskan persentase jenis kesalahan yang dilakukan oleh siswa, yang menunjukkan persentase kesalahan tertinggi terjadi pada soal nomor 2 yakni dengan total persentase $63,89 \%$ dan terendah terjadi pada soal nomor 6 yakni dengan total persentase 3,94\%. Sedangkan jenis kesalahan yang paling banyak terjadi yaitu pada jenis kesalahan konsep, diikuti dengan jenis kesalahan menghitung, jenis kesalahan soal tidak direspon, jenis kesalahan mengguna kan data, jenis kesalahan strategi menjawab dan yang terakhir jenis kesalahan matematis.

Besarnya kesalahan siswa pada masingmasing jenis kesalahan pada setiap butir soal materi GLBB (Gerak Lurus Berubah Beraturan) diperoleh kesalahan terbesar terjadi pada jenis kesalahan konsep yaitu pada soal no 2 dengan persentase kesalahan 55,56\%, sedangkan kesalahan tertinggi berikutnya juga terjadi pada jenis kesalahan konsep yakni persentase kelasalannya 27,78\%. Pembahasan analisis kesalahan yang dilakukan siswa pada butir soal ketiga yaitu materi GLBB (Gerak Lurus Berubah Berarturan) Horizontal diuraikan sebagai berikut. 
Tabel 1. Persentase siswa yang melakukan kesalahan pada materi kinematika gerak lurus

\begin{tabular}{|c|c|c|c|c|c|c|c|}
\hline \multirow{2}{*}{ Indikator Kesalahan } & \multicolumn{6}{|c|}{ Persentase Siswa yang Melakukan Kesalahan (\%) } & \multirow{2}{*}{$\begin{array}{c}\text { Rata-rata Setiap } \\
\text { Jenis Kesalahan } \\
(\%)\end{array}$} \\
\hline & Soal 1 & Soal 2 & Soal 3 & Soal 4 & Soal 5 & Soal 6 & \\
\hline Kesalahan Konsep & 27,78 & 55,56 & 12,50 & 22,22 & 9,72 & 1,39 & 21,45 \\
\hline $\begin{array}{l}\text { Kesalahan } \\
\text { Menggunakan Data }\end{array}$ & 23,61 & 0 & 0 & 1,34 & 1,39 & 0 & 4,39 \\
\hline $\begin{array}{l}\text { Kesalahan Menghitung } \\
\text { Data }\end{array}$ & 0 & 2,78 & 4,17 & 22,22 & 23,61 & 18,06 & 12 \\
\hline $\begin{array}{l}\text { Kesalahan Strategi } \\
\text { Menjawab }\end{array}$ & 0 & 5,56 & 19,44 & 0 & 0 & 0 & 4 \\
\hline Soal Tidak Direspon & 1,39 & 0 & 22,22 & 2,78 & 2,78 & 4,17 & 5,56 \\
\hline Kesalahan Matematis & 0 & 0 & 4,17 & 4,17 & 0 & 0 & 1,39 \\
\hline $\begin{array}{l}\text { Total Siswa yang } \\
\text { melakukan kesalahan } \\
\text { Setiap Soal }\end{array}$ & 52,78 & 63,89 & 62,50 & 52,73 & 37,50 & 3,94 & - \\
\hline
\end{tabular}

a. Analisis jenis kesalahan konsep

Soal ini diberikan untuk mendeteksi kesalahan dengan jenis soal "Disajikan sebuah ilustrasi tentang gerak dua benda, peserta didik dapat menerapkan persamaan GLBB untuk menentukan waktu bertemu antara dua benda yang mengalami GLBB". Berikut soal yang disajikan:

Mobil A bergerak dengan kecepatan awal $20 \mathrm{~m} / \mathrm{s}$ berada $50 \mathrm{~m}$ di depan Mobil B yang bergerak dengan kecepatan awal 15 $\mathrm{m} / \mathrm{s}$. Jika mobil A mengalami percepatan $2 \mathrm{~m} / \mathrm{s}^{2}$ dan mobil B mengalami percepatan $4 \mathrm{~m} / \mathrm{s}^{2}$, maka pada detik keberapakah mobil A bertemu dengan mobil B ?

Melalui soal ini, siswa mengalami kesalahan konsep sebanyak 55,56\%. Siswa yang mengalami kesalahan konsep karena tidak bisa membedakan penggunaan setiap rumus yang ada pada GLBB Horizontal. Dari sekian banyak rumus GLBB Horizontal yang ada, siswa tidak memahami konsep setiap penggunaan rumusnya, sehingga saat menyelesaikan soal mengenai GLBB Horizontal, siswa bingung dalam menentukan rumus yang tepat.
Siswa tidak menganalisa soal dengan baik, saat menentukan rumus yang tepat untuk digunakan, siswa tidak memahami peristiwa apa yang terjadi pada soal dan tidak memperhatikan data yang diketahui pada soal, yang dapat digunakan pada rumus dalam menyelesaikan soal tersebut. Hal ini terjadi karena siswa tidak memahami konsep fisika dalam peristiwa yang terjadi pada soal tersebut, sehingga kesalahan konsep rata-rata tertinggi dibanding jenis kesalahan yang lain yaitu $21,45 \%$. Hasil ini sesuai dengan hasil penelitian Sufi Ani (2011) yang mendapatkan kesalahan konsep yang lebih besar yaitu $68 \%$.

b. Analisis jenis kesalahan menggunakan data

Jenis kesalahan menggunakan data, berdasarkan Tabel 1 diperoleh persentase tertinggi pada soal 1 yaitu $23,61 \%$ dengan rata-rata kesalahan 4,39\%. Jenis kesalahan ini secara rata-rata termasuk rendah tingkat kesalahannya. Hal ini menandakan bahwa siswa sudah cukup teliti dalam menggunakan data.

c. Analisis jenis kesalahan menghitung

Terkait jenis kesalahan menghitung, siswa yang mengalami kesalahan tertinggi terdapat pada soal nomor 5 yaitu 23,61\%, dengan ratarata jenis kesalahan ini $12 \%$. Kesalahan hitungan yang terjadi adalah kesalahan yang 
sederhana, namun sering terjadi karena kurang telitinya siswa saat melakukan perkalian, pembagian, pengurangan dan penambahan bilangan. Hasil penelitian Sufi Ani (2011) malah mendapatkan kesalahan menghintung sebesar $60 \%$.

\section{d. Analisis jenis kesalahan strategi menjawab}

Jenis kesalahan strategi menjawab, didapatkan siswa yang banyak mengalami kesalahan pada soal nomor 3 yaitu 19,44\%, dengan rata-rata jenis kesalahan ini $4 \%$. Kesalahan strategi ini disebabkan saat menyelesaikan soalnya, siswa bingung dan tidak tau strategi yang tepat dalam menggunakan rumus dan persamaanya, sehingga siswa mengalami kesalahan dalam strategi menjawab soal tersebut.

\section{e. Analisis jenis kesalahan soal tidak direspon}

Jenis kesalahan soal tidak direspon yang tertinggi terdapat pada soal nomor 3 yaitu $22,22 \%$ dengan rata-rata jenis kesalahan ini termasukm rendah yaitu $5,56 \%$. Jika dianalisa kertas jawaban siswa-siswa tersebut, ternyaata siswa yang tidak merespon, dikarekanakan siswa tidak tau penyelesaian soal tersebut. Dapat dikatakan bahwa siswa-siswa tersebut tidak memahami konsep penyelesaian soalnya, karena siswa mengerjakannya hanya sampai tahap menuliskan soal "apa yang ditanya", siswa dalam hal ini tidak memberi jawaban.

\section{f. Analisis jenis kesalahan matamatis}

Jenis kesalahan matematis terdapat pada soal nomor 3 dan 4 dengan persentase masingmasing sebesar $4,17 \%$, sedanglan soal lainnya $0 \%$. Sehingga rata-rata jenis kesalahan ini adalah yang terkecil hanya $1,39 \%$. Kesalahan matematis yang dilakukan siswa yaitu siswa belum cukup memahami bahwa pada konsep matematika, jika kedua ruas memiliki komponen yang sama, maka komponen tersebut tidak bisa dicoret atau dihilangkan apabila setiap ruas merupakan operasi penjumlahan atau pengurangan, bukan perkalian atau pembagian. Berikut contoh persamaan yang kebanyakan siswa melakukan kesalahan:

$$
\mathrm{x}_{0 \mathrm{~A}}+\mathrm{v}_{0 \mathrm{~A}} \cdot \mathrm{t}+\frac{1}{2} \mathrm{a} \cdot \mathrm{t}^{2}=\mathrm{v}_{0 \mathrm{~B}} \cdot \mathrm{t}+\frac{1}{2} \mathrm{a} \cdot \mathrm{t}^{2}
$$

Persamaan (1) diketahui t pada ruas kiri tidak bisa dihilangkan dengan $t$ pada ruas kanan, karena operasi matematika pada kedua ruas merupakan operasi penjumlahan, namun ada siswa yang mencoret $t$ tesebut, sehingga terjadi kesalahan matematis. Hasil penelitian menunjukkan bahwa masing-masing siswa memiliki tingkat kesulitan yang berbagai macam, sehingga mengalami kesalahan yang cukup variatif. Dapat dilihat dalam setiap jenis kesalahan masing-masing soal, jika ditinjau dari kajian sebelumnya dapat dijelaskan dalam uraian berikut:

\section{Kesalahan konsep}

Faktor penyebab siswa melakukan kesalahan konsep menurut Hastuti (2013) yaitu siswa tidak memahami materi yang disampaikan oleh guru, siswa tidak mempelajari kembali materi yang belum dipahaminya, siswa tidak berani bertanya kepada guru apabila belum memahami materi, siswa hanya belajar dari buku catatan yang kurang lengkap, kesiapan siswa yang kurang maksimal, dan siswa tidak mengikuti pelajaran. Solusi untuk mengatasi kesalahan konsep menurut Suroso (2016) yaitu siswa diharapkan lebih rajin dalam belajar, siswa diharapkan mengerjakan soal-soal, siswa diharapkan bertanya kepada guru apabila ada materi yang belum dipahami. Bagi guru diharapkan memperjelas konsep yang diberikan kepada siswa, memberikan motivasi kepada siswa supaya siswa menyukai pembelajaran fisika, sehingga siswa lebih berkonsentrasi dalam belajar dan aktif dalam kegiatan pembelajaran.

\section{Kesalahan strategi}

Menurut Suroso (2016) kesalahan startegi merupakan kesalahan dalam menggunakan data dan dalam penentuan langkah penyelesaian soal. Faktor penyebab siswa melakukan kesalahan strategi yaitu siswa tidak membaca petunjuk mengerjakan soal, siswa kurang paham dengan apa yang ditanyakan dari soal, dan siswa kurang latihan soal yang bervariasi (Hastuti et al., 2012). Solusi untuk mengatasi kesalahan strategi yaitu guru seharusnya lebih sering mengingat kan siswa untuk lebih teliti dalam membaca soal dan menghitung, guru diharapkan lebih sering memberikan latihan kesalahan strategi dalam menyelesaikan soal. 
3. Kesalahan hitung dan matematis

Menurut Suroso (2016) kesalahan hitung merupakan kesalahan dalam melakukan operasi hitung. Faktor penyebab siswa melakukan kesalahan hitung yaitu kurangnya pemahaman konsep siswa dalam menghitung dan siswa kurangnya ketelitian siswa dalam menghitung (Hastuti, 2013). Solusi untuk mengatasi kesalahan hitung yaitu guru diharapkan lebih sering mengingatkan siswa untuk lebih teliti dalam menghitung, serta meneliti kembali pekerjaannya jika telah selesai mengerjakan yang sesuai dengan hasil kajian (Suroso, 2016).

\section{Kesalahan soal tidak direspon}

Kesalahan siswa terkait tidak menjawab soal disebabkan beberapa faktor, antara lain siswa tidak mengerti perintah soal atau tidak mengerti langkah awal dalam menyelesaikan soal, siswa kesulitan dalam menentukan rumus yang digunakan dalam menyelesaikan soal, dan waktu untuk menyelesaikan soal telah habis (Dajtmiko Hidayat, 2018). Solusi untuk mengatasi kesalahan ini yaitu siswa seharus nya tidak terpaku karena telah mengelami kesulitan pada soal sebelumnya, dan siswa seharusnya dapat memperkirakan waktu yang telah disediakan oleh guru untuk menyelesai kan soal yang ada.

\section{Kesalahan menggunakan data}

Faktor penyebab siswa melakukan kesalahan menggunakan data menurut yaitu siswa kurang teliti dalam membaca soal, siswa tidak tahu lambang atau simbol besaran fisika, dan siswa kurang latihan soal (Hastuti et al., 2012). Solusi mengatasi kesalahan menggunakan data dalam menyelesaikan soal fisika yaitu siswa seharusnya dapat lebih teliti dan cermat dalam membaca dan memahami soal yang ada, serta siswa harus sering melakukan latihan soal-soal fisika agar dapat dengan mudah mengingat dan hafal akan lambang dan simbol besaran fisika.

Berdasarkan hasil analisis ditemukan dari 6 jenis kesalahan yang dialami siswa dalam menyelesaikan persoalan fisika khususnya pada materi GLB yang diujikan dengan jenis kesalahan yang dominan yaitu kesalahan konsep $21,45 \%$ yang disebabkan kurangnya pemahaman siswa dalam konsep fisika pada materi gerak lurus baik dalam konsep dasar ataupun penerapan rumus-rumus dalam penyelesaian soal-soal fisika. Jenis kesalahan dominan kedua yaitu kesalahan menghitung data $12 \%$ karena masih lemahnya ketelitian dan kurangnya latihan menerapkan konsep matematis dalam menyelesaikan soal fisika.

\section{Kesimpulan dan Saran}

Hasil analisis data dan peneltian yang telah dilakukan dapat disimpulkan bahwa terdapat 6 jenis kesalahan siswa dalam menyelesaikan soal fisika tentang gerak lurus di SMA Negeri 5 Pekanbaru, jenis kesalahan yang paling banyak dilakukan oleh siswa yaitu kesalahan konsep dan kesalahan menghitung data. Sedangkan kesalahan yang paling kecil adalah kesalahan matematis. Untuk itu kecenderungan kesalahan yang doninan dialami oleh siswa dalam pembelajaran fisika pada materi GLB adalah jenis kesalahan konsep dan kesalahan menghitung data.

Diharapkan dalam penyelesaian persoalan konsep fisika khususnya materi GLBB untuk menekankan pada pemahaman konsep dan prosedur menghitung data yang lebih optimal, sehingga dapat meminimalisir atau menghindari terjadinya jenis kesalahankesalahan tersebut

\section{Daftar Pustaka}

Andika Rahmat, 2016. Analisis Kesalahan Siswa dalam Menyelesaikan Soal-Soal pada Materi Hukum Kirchoff. Jurnal Penelitian FKIP UNTAN, 6(10): 1-16.

Agustini Baya Sari, 2015. Analisis Kesalahan Siswa dalam Menyelesaikan Soal Fisika pada Materi Kalor di Kelas X,9 SMA N 2 Lubuklanggau Tahun Ajaran 2015/ 2016. Jurnal Penelitian STKIP-PGRI.

Dajtmiko Hidayat, 2018. Analisis Kesulitan dalam Penyelesaian Permasalahan Ruang Dimensi Dua. Jurnal Pendidikan Matematika.

Depdiknas, 2003. Kurikulum 2004 Standar Kompetensi Mata Pelajaran Fisika Sekolah Menengah Atas dan Madrasah Aliyah. Pusat Kurikulum Balitbang, Jakarta.

Dewi, Siyami Intan, K., \& Kusrini, 2015. Analisis Kesalahan Siswa dalam 
Menyelesaikan Soal Fisika pada Meter Kalor di Kelas $\mathrm{X}_{9}$ SMA $\mathrm{N} \quad 2$ Lubuklinggau Tahun Pelajaran 2015/ 2016. Jurnal Ilmiah Pendidikan Fisika STKIP-PGRI Lubuklinggau.

Haryadi, 2015. Dasar Kemampuan Fisika. Erlangga, Jakarta.

Hastuti, I., Surantoro Toro, \& Dwi Teguh Rahardjo, 2012. Analisis Kesalahan dalam Menyelesaikan Soal Materi Pokok Kalor pada Siswa Kelas X SMA. Jurnal Materi dan Pembelajaran Fisika, 2(1): 1-11.

Kereh, 2014. Miskonsepsi Kesalahan Siswa Mengerjakan Soal Fisika. Jurnal Penelitian FKIP UNTAN.

Muhammad Hasbi, 2012. Pengaruh Kemampuan Trigonometri Terhadap Kemampuan Fisika Dikaitkan dengan Gaya Kognitif Mahasiswa Program Studi Pendidikan Fisika FKIP Universitas Tadulako. Jurnal Pendidikan Matematika FKIP Tadulako.

Nanang Martono, 2010. Metode Penelitian Kuantitatif Analisis Isi dan Analisis Sekunder. PT. Raja Grafindo Persada, Jakarta.

Nathanael Mariono, 2011. Hubungan Fisika dan Matematika. (online). (http:// gurufisikamuda.blog.spot.co.id/2011/02/ hubungan-fisika-dan-matematika. html, diakses tanggal 25 Mei 2019).

Pahini, Nani, 2013. Pengaruh Skill Multirepresentasi Siswa terhadap Hasil Belajar Fisika pada Model Pembelajaran Exsclusive. Jurnal Pembelajaran Fisika, 2(5): 133.

Riskowati, 2013. Hubungan Fisika dengan Logika Pemahaman Siswa. Jurnal Penelitian FKIP UNTAN.

Sufi Ani, 2011. Profil Kesalahan Siswa SMA dalam Perngerjaan Soal pada Materi Momentum dan Impuls. Jurnal FKIP UNS.

Suroso, 2016. Analisis Kesalahan Siswa dalam Mengerjakan Soal-soal Fisika Thermodinamika pada Siswa SMS Negeri 1 Magetan. Jurnal Edukasi Matematika dan Sains (JEMS), 4 (1): 8-18.

Tri Wahyu Ningsih, Trustho Raharjo, \& Dyah Fitriana Masithoh, 2013. Pembuatan Instrumen Tes Diagnostik Fisika SMA Kelas XI. Jurnal Pendidkan Fisika 1(1): 111-117. FKIP UNS. Surakarta.

Wijayanto, Setyo Hadi, 2008. Structural Equation Modeling dengan LISREL 8.8. Graha Ilmu, Yogyakarta. 